\title{
TERESA DE ÁVILA Y LA POESÍA CANCIONERIL TERESA DE ÁVILA AND THE SONGBOOK POETRY
}

\author{
Armando López CASTro \\ Universidad de León
}

\section{RESUMEN:}

Teresa de Jesús escribió poesía porque tenía un alma musical y sabía dar ritmo a sus poemas. Es una música que surge de la oscuridad y habla de lo profundo, destinada a elevarse desde la fuerza de su dolorosa espera, de ahí que invite a la plegaria con el estremecimiento de ser sustancia viva. Vueltos hacia su propio interior, sus poemas potencian su energía sonora desde la desnudez de su fingida retórica y nos hacen volar el oído hacia lo sobrenatural, buscando la recuperación del orden perdido.

Palabras clave: poesía, intimidad, desnudez, música, armonía.

\section{ABSTRACT:}

Teresa de Jesús wroter poetry because she had a musical soul and knew how to give rhythm to her poems. It is a music that emerges from the darkness and speaks from the deep, destined to rise from the force of its painful waiting, hence the invitation to prayer with the shudder of being living substance. Turned towards his own interior, his poems enhance his sound energy from the nakedness of his feigned rhetoric and make us blow our ears towards the supernatural, seeking the recovery of the lost order. KEYWORDS: poetry, intimacy, nudity, music, harmony.

En la formación juvenil de Teresa de Ávila destacan dos lecturas: los libros de caballerías y la poesía de cancionero. Respecto a los primeros, dice su biógrafo Francisco de Ribera:

Diose, pues, a estos libros de caballería, sino de vanidades, con gran gusto, y gastaba en ellos mucho tiempo; y como su ingenio era tan excelente, así bebió aquel lenguaje y estilo, que dentro de pocos meses ella y su hermano Rodrigo de Ahumada compusieron un libro de caballerías con sus aventuras y ficciones, y salió tal que habría harto que decir de él. 
Hay que tener en cuenta que los libros de caballerías eran los preferidos en todas las clases sociales de la época, porque respondían al ideal utópico del Emperador como modelo de caballero cristiano contra los infieles, turcos y musulmanes. En cuanto a la poesía cancioneril, el gusto por los contrastes y paradojas logró un gran desarrollo en la corte de los Reyes Católicos, donde la canción tradicional sirvió de molde para hacer una poesía conceptual, de lucha entre la razón y la pasión, en la que el ingenio está al servicio de la intensidad expresiva. De ambas lecturas, que constituían la moda del momento, dice Teresa en el Libro de la vida: "Era tan extremo lo que en esto me embebía, que si no tenía libro nuevo no me parece tenía contento" $(2,1)$. Tanto la ficción de los libros de caballerías como el artificio de la poesía cancioneril buscan estimular la imaginación del lector, hacer de la escritura un riesgo de vivir esa radicalidad profunda y permanente en que consiste la experiencia mística, con la que se pretende poner el alma en los escritos para alcanzar un nuevo nivel de realidad ${ }^{1}$.

Sin embargo, frente a la lectura de los libros de caballerías, que responde a un momento de exaltación imperial, aunque la interpretación alegórica, por parte de la ortodoxia católica, haya querido ver, en la fidelidad de Amadís a Oriana una transposición del amor del alma a su esposo Cristo, de modo análogo a la Amada y el Amado del Cantar de los Cantares, la supervivencia de la poesía cancioneril, objeto de este ensayo, reviste una mayor complejidad, tanto por lo que se refiere a la difusión de los temas, sobre todo amatorios, en el ámbito de los conventos carmelitas, como a la conocida técnica de los contrafacta o "versiones a lo divino". Ambas modalidades, la cancioneril y la conventual, eran conocidas por Teresa, que se esforzó por integrarlas en su escritura, dondeel lenguaje coloquial cumple una función redentora de recuperación, de devolver la palabra a su sentido original. Para comunicar su experiencia mística, Teresa siente la necesidad de dotarse de una nueva forma de escritura, saltándose las convenciones que el código cancioneril impone y volviendo a los orígenes perdidos. En cuanto al lenguaje cancioneril, donde nada es dicho directamente, sino que todo es insinuado, el poeta se debate entre la apuesta y el riesgo, ya que la realidad nunca se ofrece en su transparencia. Téngase en cuenta que la visión de lo real, tal como se ofrece en los poemas de los Cancioneros más conocidos (Baena, Palacio, Herberay, Estúñiga y General), no se hace de manera directa, sino oblicua, literaturizada, es decir, convertida en materia de ficción, que sólo puede interpretarse desde los códigos poéticos y cortesanos de los lectores del siglo XV. Teresa de Ávila, como lectora, conocía el lenguaje retórico de estos códigos, pero como sus monjas no lo entendían, tenía que

\footnotetext{
${ }^{1}$ Para la cita de las obras teresianas, sigo la edición conjunta de Efrén de la Madre de Dios y Otgger Steggink, Santa Teresa de Jesús, Obras completas, Madrid, BAC, 1962; novena edición, 1977, y dentro de ella, la quinta reimpresión, 2012. En cuanto a la cita de Ribera, está sacada de su obra, La vida de la madre Teresa de Jesús, Salamanca, Pedro Laso, 1590, I, cap. 5. Nueva edición revisada por el P. Jaime Pons (Barcelona, Gustavo Gili, 1908).
} 
transformarlo, presentarlo sin artificio para que pudiera ser comprendido. Así pues, toda esa "elegancia desafeitada que deleita en extremo", de la que habla fray Luis de León en su "carta dedicatoria" de la edición príncipe, lo que revela, en el fondo, es una "voluntad de estilo" para expresar lo inefable de la experiencia mística. Hay, por tanto, en su escritura, tanto en prosa como en verso, pues ambas salieron de la misma pluma, un afán por hacerse entender, lo cual implica la afirmación personal de una voz interior, que surge espontáneamente y deja escuchar su ritmo. Esa voz natural, que todo escritor busca y necesita, es la que da unidad y fuerza a la escritura teresiana, que se despliega en nuevas formas a partir de su penetración en el fondo del alma. Pocos como ella han expresado la necesidad de abismarse hasta llegar al punto extremo de la interioridad, donde la palabra se constituye, donde el lenguaje se desprende de la lógica y se hace inminencia de cuanto puede ser. Escribir sería así una apuesta radical por entrar en lo desconocido, en el profundo misterio de lo no visible, propia del que se aventura en la búsqueda de lo absoluto².

En cuanto a las poesías que se recitaron en los conventos del Carmelo, se trata de composiciones ocasionales e improvisadas, sujetas a múltiples variantes, lo que hace difícil su fijación textual, y cuya supervivencia viene dada por el canto. Asociadas al ciclo litúrgico, desde los tiempos de san Francisco, y a las profesiones monásticas, a partir de la Contrarreforma, estas poesías fueron compuestas para ser cantadas colectivamente, utilizando la música y el baile como elementos básicos, y se sirvieron de la métrica tradicional, con predominio de la copla y el villancico. Un buen ejemplo de esta poesía conventual sería el ciclo dedicado a "los hábitos y velos", costumbre que se perpetúa en los distintos conventos carmelitas y adquiere una función social a través de los "pliegos de profesión". La solemnidad de estos actos celebrativos, asegurada desde 1572 por Juana de Austria y después por Felipe II, forma parte de una ceremonia privada, en la que aparece el nombre de la profesa, del convento y de la capilla musical que interviene en el acto, elementos básicos de un ceremonial en el que se da el paso de la vida seglar a la religiosa y donde la música juega un papel primordial. Y dado que el villancico desde su origen es un género para ser cantado, pues aparece compuesto por el estribillo y una serie de coplas que glosan su contenido, los llamados "juegos de villancicos", creados para una determinada ocasión, revelan una variedad formal, tanto por lo que se refiere a los símbolos de la tradición litúrgica (el velo, la corona), como al repertorio de los recursos métricos. Por otra parte, los "pliegos de profesión", al surgir después de la clausura impuesta por el Concilio de

\footnotetext{
2 Sobre la ambigüedad o polivalencia, propia de la lírica cancioneril, remito a los estudios de K.Whinnom, La poesía amatoria cancioneril en la época de los Reyes Católicos, University of Durham, 1981; y de J. Casas Rigall, Agudeza y retórica de la poesía de cancionero, Universidad de Santiago, 1995. En cuanto al impulso por expresar la propia intimidad en la escritura, véase el ensayo de J.Marichal, "Santa Teresa en el ensayismo hispánico", en La voluntad de estilo, Barcelona, Seix Barral, 1957, pp.71-80.
} 
Trento (1545-1564), pertenecen al reducido ámbito de la escritura femenina, sometida entonces a la marginación y al silencio. Tal vez por eso, surgió la voz de Teresa para imponerse a un ambiente receloso y hostil, y en cuya escritura la forma del epitalamio, trasladada alegóricamente al desposorio espiritual, se convierte en una metáfora erótica y los versos cantados en una expansión espontánea de intimidad. El hecho de que la mayor parte de los villancicos teresianos hayan sido concebidos para ser cantados colectivamente por la comunidad carmelita en el acto de una profesión, que hacía efectiva la relación entre la renuncia de este mundo y la fe en el más allá, es porque su escritura forma parte de una cultura refinada, que incluye saber cantar, bailar y escribir poesía. Para Teresa, la actividad de escribir versos va unida a la posibilidad de expresar sus experiencias místicas, de salvar el abismo que la separa entre lo humano y lo divino, a través de una voz interior, que ha sido acallada, pero no abolida, que permanece, a lo largo del proceso místico, en trance de constituirse, latente y en sazón. Esa voz, que se reduce a decir lo esencial sin romper en ningún momento el ritmo que la sustenta, tiene un gran poder generador, pues no sólo da vida al pensamiento, sino que además le permite al escritor liberar sus emociones más intensas, ser alguien diferente a través de la máscara o el disfraz. Teresa se reinventó una y otra vez en su escritura para dar a su voz la libertad que necesita, para hacerla más natural y flexible a través del canto 3 .

En la época de Teresa de Ávila, el acceso de la mujer a la vida pública forma parte de un lento despertar. Los estereotipos femeninos existentes, como la "casada sometida", la "pecadora arrepentida" o la "virgen necia", encubrían, bajo el disfraz del temor de la honra o el recato de la vergüenza, una falta de libertad. Por eso, en el Quijote, la libertad que Marcela no puede hallar en la sociedad, la busca en la naturaleza: "yo nací libre y para poder vivir libre escogí la libertad de los campos" (I, 13). Libertad del amor, que entraña un deslumbrante fingimiento ("e que siempre se precie e se finja de ser enamorado", leemos en el "Prólogo" del Cancionero de Baena), mediante el cual lo decible es capaz de fundirse con lo indecible, pues tanto el poeta como el místico buscan comunicarse con una alteridad desconocida. En este sentido, llama mucho la atención el hecho de que Teresa haya decidido quemar su obra Meditaciones sobre los cantares, compuesta entre 1570 y 1577, es decir, entre Camino de perfección y las Moradas, que ella misma había glosado para las monjas de sus conventos, tras oír el informe del teólogo dominico Diego de Yanguas, que reprueba el comentario de Teresa por no parecerle adecuado que una mujer escribiese sobre la Sagrada Escritura. Si tenemos

\footnotetext{
${ }^{3}$ Para la relación entre mística y poesía en los conventos carmelitas, tengo en cuenta el ensayo de E.Orozco, "De la experiencia mística a la experiencia poética. Oración y poesía”, en Expresión, comunicación y estilo en la obra de Santa Teresa, Diputación de Granada, 1987, pp.127-141. Sobre los pliegos poéticos relativos a la profesión de fe, véase el ensayo de N.Baranda, "Tomas de velo: deslindes preliminares", en Bulletin Hispanique, 113 / 1 (2011), pp.269-296.
} 
en cuenta que el origen del poema bíblico hay que buscarlo en los cantos egipcios y los himnos sumeroacadios, anteriores al siglo IV y llenos de alusiones sexuales, y que los cabalistas más antiguos subrayan su erotismo, ¿no sería la quema del texto una forma de liberarse de los límites de la ortodoxia, de hacer del lenguaje erótico, que apunta a la unidad de la primera pareja, un medio de fundir mística y poesía? De los siete villancicos teresianos que se conservan, los tres más destacados, " $¡ O$ Oh hermosura que excedéis!", "Vivo sin vivir en mí" y "Ya toda me entregué y di", giran en torno al motivo central del amor, elemento esencial de la experiencia mística, en cuanto hace posible el encuentro con el otro que nos reconoce. De los tres poemas citados, que participan de la destrucción para mantener viva una textualidad abierta, como si fuera un abismo en el que todos los nombres son posibles, el primero de ellos es el que mejor expresa esa identificación de los amantes en la nada, que deja el lenguaje al borde de su propia negación y le permite expresar aquello que no puede ser dicho. El poema dice así:

\section{¡OH HERMOSURA QUE EXCEDÉIS}

¡Oh hermosura que excedéis

a todas las hermosuras!

Sin herir dolor hacéis, y sin dolor deshacéis

5 el amor de las criaturas.

¡Oh ñudo que así juntáis dos cosas tan desiguales!, no sé por qué os desatáis, pues atado fuerza dais

10 a tener por bien los males.

Juntáis quien no tiene ser con el ser que no se acaba: sin acabar acabáis, sin tener que amar amáis,

15 engrandecéis nuestra nada.

El origen del villancico hay que buscarlo en una carta de Teresa a su hermano Lorenzo, del 2 de enero de 1577, en la que, recordando este poema, le dice: “Ahora se me acuerda uno que hice una vez, estando con harta oración, y parecía que descansaba más". Se trata, pues, de un poema relacionado con la experiencia mística ("estando con harta oración"), experiencia que sobrepasa al lenguaje (“'Oh hermosura que excedéis!"), vista en términos platónicos, y que, para poder expresarla, el sujeto poético utiliza los siguientes recursos: la marca subjetiva de la exclamación, que abre las dos primeras 
estrofas y muestra la actitud del hablante; el predominio de la forma verbal en plural ("excedéis", "hacéis", “deshacéis", "juntáis", "desatáis", “dais”, “acabáis", "amáis", "engrandecéis"), que dan un matiz auto-referencial al discurso; el uso de la paradoja ("sin acabar acabáis, / sin tener que amar amáis"), forma de la contradicción interna; y el símbolo del nudo de amor (“¡Oh ñudo que así juntáis / dos cosas tan desiguales!”), que ya aparece en Raimundo Lulio y Jan van Ruysbroeck, y que sirve para unir a Dios y al alma. Con todo, lo importante es que tales recursos se unifican al final en la estructura religiosa de la nada ("engrandecéis nuestra nada"), que se convierte así en el centro integrador del poema. En el contexto ficticio del villancico, la nada aparece como ámbito de plenitud, donde confluyen la experiencia del místico y la experiencia del poeta ${ }^{4}$.

El segundo villancico, "Vivo sin vivir en mí", es el más conocido y famoso de los poemas teresianos. Lo había oído Teresa de boca de Isabel de Jesús, novicia de las carmelitas de Salamanca, pero el estribillo es más antiguo, pues aparece ya en una letra recogida por Diego de San Pedro ("Este triste más que honbre / que muere porque no muere / bivirá quanto biviere ( sin su nombre"), en su novela epistolar Tractado de amores de Arnalte e Lucenda (1491); en una canción de Vicente Escrivá ("Ven, muerte, tan escondida"), recogida en el Cancionero general (1511); y en una cantiga del Cancioneiro Geral (1516), de Garcia de Resende, atribuida a don Juan de Meneses ("que no byuo, porque byuo, / y muero, porque no muero"), versos que inspiraron tanto a Teresa de Ávila ("Vivo sin vivir en mí"), como a Juan de la Cruz ("En mí yo no vivo ya"). Las variantes de estas canciones, recogidas por los distintos Cancioneros, formaron parte de la poesía lúdica de la galantería cortesana, destinada a la diversión de un público minoritario (en el "Prologo" al Cancionero general, Hernando del Castillo nos dice que dio su obra a la imprenta "para común utilidad y pasatiempo"), cuyos contactos y supervivencias, asegurados por la música y la danza, sirvieron para que los estribillos de estas canciones quedaran en la memoria de los oyentes. Así sucede con este poema, donde mística y poesía confluyen para poder expresar el sueño de una experiencia restaurada:

\title{
VIVO SIN VIVIR EN MÍ
}

\author{
Vivo sin vivir en mí, \\ y tan alta vida espero, \\ que muero porque no muero.
}

\footnotetext{
4 Para el mundo social de las monjas, posterior al Concilio de Trento, cuya libertad hay que buscarla en la soledad del encierro, tengo en cuenta el estudio de C.Janés, Guardar la casa y cerrar la boca, Madrid, Siruela, 2015, pp.155-185. En cuanto al símbolo del "nudo de amor", véase el trabajo de H.Hatzfeld, Estudios literarios sobre mística española, Madrid, Gredos, 1955, pp.33-143.
} 
Vivo ya fuera de mí,

5 después que muero de amor;

Pues que vivo en el Señor,

que me hizo para sí;

cuando el corazón le di

puso en él este letrero:

10 que тиеro porque no muero.

Esta divina prisión, del amor en que yo vivo, ha hecho a Dios mi cautivo, y libre mi corazón;

15 y causa en mí tal pasión ver a Dios mi prisionero, que muero porque no muero.

¡Ay, qué larga es esta vida! ¡Qué duros estos destierros,

20 esta cárcel, estos hierros en que el alma está metida! Solo esperar la salida me causa dolor tan fiero, que muero porque no muero.

25 ¡Ay, qué vida tan amarga do no se goza el Señor! Porque si es dulce el amor, no lo es la esperanza larga; quíteme Dios esta carga,

30 más pesada que el acero, que muero porque no muero.

Solo con la confianza vivo de que he de morir, porque muriendo el vivir

35 me asegura mi esperanza; muerte do el vivir se alcanza, no te tardes, que te espero, que muero porque no muero.

Mira que el amor es fuerte;

40 vida, no me seas molesta, mira que solo me resta para ganarte perderte.

Venga ya la dulce muerte, 
el morir venga ligero,

45 que muero porque no muero.

Aquella vida de arriba, que es la vida verdadera, hasta que esta vida muera, no se goza estando viva;

50 muerte, no me seas esquiva; viva muriendo primero, que тuеro porque nо тиеro.

Vida, ¿qué puedo yo darle a mi Dios que vive en mí,

55 si no es el perderte a ti, para merecer ganarle?

Quiero muriendo alcanzarle, pues tanto a mi Amado quiero, que тието porque nо тиеro.

Se suele olvidar, con bastante frecuencia, que los místicos españoles, sobre todo Teresa de Jesús y Juan de la Cruz, surgen como eslabones al final de una larga cadena, con la consiguiente capacidad de incorporar materiales de acarreo diverso, tanto de la tradición propia como ajena, destacando dentro de esta última la mística alemana y la de los Países Bajos. Los místicos germano-flamencos, aun siendo más abstractos en la exposición de sus vivencias que los españoles, no por ello dejan de aludir al proceso de mortificación de forma directa. En su Sermón sobre san Pablo dice Tauler: "En la muerte más verdadera de todas las cosas creadas se oculta la vida más dulce y más natural". De acuerdo con ello, el objeto de la mortificación no es la muerte, sino la vida, y teniendo presente esta necesidad de la muerte corporal ("Vivo, mas no yo"), el místico puede renunciar a esta vida imperfecta para ganar otra más alta y perfecta, necesaria para la consumación de su amor. Esta visión de la muerte como liberación es la que se ofrece como núcleo del poema teresiano, en donde el antiguo tópico de morir de amor ("muero de amor", v.5), es llevado a su último extremo y posibilidad. En función de esta necesidad de morir para vivir, el lenguaje del poema, con el uso de la paradoja, contenida en el estribillo ("que muero porque no muero"), presente a lo largo del poema, a la que hay que añadir la triple antítesis que se establece entre "vivir", "esperar" y "morir"; el tono exhortativo que rige el poema, subrayado mediante la forma verbal en subjuntivo ("no te tardes, que te espero", v.37), y la prosopopeya o personificación ("el morir venga ligero", v.44), que insiste en el deseo de morir para llegar al mundo celestial; la imagen de la vida como cárcel ("Esta divina prisión", v.30), que se hace posibilidad de regeneración y expresión de libertad; y la unión de la 
interrogación retórica y del quiasmo en la última estrofa, que apunta a la pérdida de lo propio para poder "merecer ganar" a Dios, todo ese lenguaje antitético lo que hace es poner de manifiesto que no hay vida sin muerte, progreso sin dolor. Así pues, para el místico, el sufrimiento, que significa el desapego o muerte de todos los sentidos, es una condición necesaria para la unión amorosa, pues cuanto más se ama, más se renuncia a toda propiedad, más libre se muestra el lenguaje en la búsqueda de lo real5.

El ritual de la caza se remonta a la más remota antigüedad. Las aves consagradas a los dioses presagiaban lo trascendente y gozaban de especial estima. Durante la Edad Media, en Castilla, la caza de cetrería tuvo un gran desarrollo: el caballo y el azor del conde Fernán González, la pérdida de los halcones y azores en el Cantar del Cid y el neblí perdido de Calisto que lo guía hasta Melibea no hacen más que revelar una amplia tradición de la cacería de amor, en la que la figura masculina del halcón, símbolo solar y fálico, persigue a la presa femenina de la garza. El dramaturgo portugués Gil Vicente conocía muy bien nuestra poesía tradicional, a la que pertenece el tópico recogido en el estribillo ("La caza de amor / es de altanería"), según nos dice en el "Romance de Flérida y don Duardos", que aparece dentro de la Tragicomedia de Dom Duardos (hacia 1522), de ahí que siga más el castellano amor cetrero, representado por el neblí perdido o halcón, que el servicial amor cortés provenzal, simbolizado por el azor encaperuzado. Si el motivo de la caza de amor fue "vertido a lo divino" durante la Contrarreforma, tal como revela la coincidencia entre el poema que comienza "Vi una garça a par del cielo", recogido en el libro Floresta de varia poesía (1562), de Ramírez Pagán, y el romance de Juan de la Cruz, "Tras un amoroso lance”, ello es debido a que ambos sentimientos, el profano y el religioso, se sustentan en un mitológico fondo común de epifanía: el enigma del deseo insatisfecho. De tal fondo enigmático participa también el villancico teresiano "Ya toda me entregué y di", en el que el motivo de la "herida de amor" sirve para mostrar la transformación de los amantes, del alma y Dios:

\section{YA TODA ME ENTREGUÉ Y DI}
Ya toda me entregué y di, $y$ de tal suerte he trocado, que mi Amado es para mí y yo soy para mi Amado.

\footnotetext{
${ }^{5}$ Aludiendo a la mediación del "Juego de Amor", que aproxima la experiencia poética a la mística, señala E.Underhill: "La conciencia mística, como hemos visto, forma parte -desde el punto de vista psicológicode ese tipo de personalidad móvil o inestable en el que también encaja el temperamento artístico. En sus titubeos en busca de la realidad trascendental, oscila fácilmente entre los extremos del placer y el dolor, en La mística, Madrid, Trotta, 2017, pp.261-262. En cuanto a la corriente literaria de los contrafacta, que se desarrolla en España a partir de la Contrarreforma, remito al estudio de Joaquín Benito de Lucas, La poesía de Santa Teresa (Entre la tradición y lo divino), Madrid, Rialp, 2015.
} 
5 Cuando el dulce Cazador me tiró y dejó herida, en los brazos del amor mi alma quedó rendida; $\mathrm{y}$, cobrando nueva vida,

10 de tal manera he trocado, que mi Amado es para mí y yo soy para mi Amado.

Hirióme con una flecha enherbolada de amor,

15 y mi alma quedó hecha una con su Criador; ya yo no quiero otro amor, pues a mi Dios me he entregado, y mi Amado es para mí

20 y yo soy para mi Amado.

La visión del místico pertenece a un mundo espiritual que se sostiene dentro de la relación amorosa entre el alma y Dios. Para expresarla, utiliza una serie de imágenes y símbolos transmitidos por la tradición, cuya forma dinámica va eliminando lo accesorio y quedándose con lo esencial. En realidad, las imágenes de la flecha y el arco, asociadas al mundo bélico y al ciervo como animal erótico, proceden de la tradición latina y del Cantar de los Cantares (8, 6-7), y están presentes en la literatura espiritual del siglo XVI, según podemos ver en el Tercer abecedario espiritual de Francisco de Osuna, obra que Teresa leyó asiduamente en su juventud, en el Cancionero sagrado de Gregorio Silvestre, y en los Escritos autobiográficos, de Luisa de Carvajal, obras de donde las tomaron los dos escritores carmelitas. En el caso de Teresa, la flecha amorosa se relaciona con el centro del corazón o profundidad de las entrañas; en el de Juan de la Cruz, con el "ciervo herido" y los "toques de amor". El lenguaje de este poema, con la fusión amorosa del estribillo ("que mi Amado es para mí / y yo soy para mi Amado"), que sintetiza en sí mismo el significado de la canción; el valor cualitativo del adjetivo antepuesto ("el dulce Cazador"), que revela una cualidad escogida por el hablante; la reiteración de la forma verbal en pretérito perfecto ("he trocado"), expresión de la transformación amorosa; y la imagen del dardo de amor ("Hirióme con una flecha / enherbolada de amor"), no hace más que subrayar la transformación de una experiencia amorosa, de la que participan por igual mística y poesía, y que es rasgo de la realidad trascendente.

Además, la imagen de la flecha guarda una relación directa con la visión del dardo, que se ofrece en el célebre pasaje del Libro de la vida $(29,13)$, donde Teresa describe el episodio de su transverberación: “Víale en las manos un dardo de oro largo, y al fin de el hierro me parecía tener un poco de fuego; éste me parecía meter por el corazón algunas 
veces y que me llegaua a las entrañas. Al sacarle, me parecía las lleuaua consigo, y me dejaua abrasada en amor grande de Dios". Por otra parte, debido a la propagación de la literatura religiosa española en la Inglaterra de los Estuardo a lo largo del siglo XVI, de la cual sería un buen ejemplo la traducción del Tratado de la oración y la meditación, de fray Luis de Granada, con sucesivas ediciones a partir de 1592, no es difícil ver el contacto de los poetas metafísicos ingleses del siglo XVII con la vida y doctrinas de Teresa de Jesús, según se percibe en el poema "The Flaming heart", de Richard Crashaw, publicado en 1648, donde el éxtasis místico va unido a la herida de amor ("Porque en el campo del amor / nunca se ha encontrado / armas más noble que una herida", vv.70-72), y construido de acuerdo con las imágenes del arte barroco, que se mueve de lo concreto a lo abstracto, según vemos en la famosa escultura de Bernini, conservada en la iglesia de Santa María della Vittoria de Roma, donde el movimiento del dardo hacia el centro del corazón apunta a un erotismo integrador. Desde este punto de vista, el éxtasis místico, que responde a una conjunción con lo trascendente, reside en el contacto con el Amado, que se experimenta en trance irresistible entre las profundidades de la quietud y las cimas del rapto, y en donde el lenguaje, al elevarse al mundo de la contemplación, huye de lo discursivo y nombra directamente lo inefable ${ }^{6}$.

La lírica peninsular de la Baja Edad Media, la que se cultiva desde el último tercio del siglo XIV hasta principios del siglo XVI, se asienta sobre un común parentesco histórico: la tradición clásica latina, la unidad de la liturgia cristiana y el ejemplo de los trovadores provenzales. De los poetas latinos, sobre todo Virgilio, Horacio y Ovidio, aprenden los poetas cortesanos del siglo XV la perfección formal; de la unidad cristiana que lo preside, el principio del orden jerárquico; y de la tradición provenzal del amor cortés, la admiración por la belle dame sans merci. De modo general, la poesía que se recoge en los Cancioneros, desde el Cancionero de Baena hasta el Cancionero general, es un tipo estilizado, que se complace en el juego del amor y cuya sutileza retórica, que cuenta con la aprobación de un público entendido, muestra una poesía conceptual, más predispuesta al análisis racional que a la expansión íntima. Y si los Cancioneros son, en cada momento, repertorios de canciones, lo que hoy llamaríamos antologías colectivas, donde cuenta más la forma que el contenido, será necesario analizar la gramática que los aglutina, la cual refleja un mismo pensamiento y una misma técnica formal. Con el Cancionero musical de Palacio, elaborado bajo el reinado de los Reyes Católicos, y el Cancionero general, impreso por Hernando del Castillo en 1511,

\footnotetext{
${ }^{6}$ Sobre el motivo de la caza de amor, del que existe una abundante bibliografía, habría que destacar el estudio de M.Thiébaux, The Stag of Love. The chase in medieval literature, Cornell University Press, 1974. Respecto a la mención de la "herida de amor" en la escritura teresiana, véase J.Poitrey, Vocabulario de Santa Teresa, Madrid, Fundación Universitaria Española / Universidad Pontificia de Salamanca, Madrid, 1983, p.609. En cuanto a la relación de la flecha y el arco con las imágenes eróticas, tengo en cuenta el trabajo de F.Gómez Solís, Imágenes eróticas y bélicas de la literatura espiritual española (Siglos XVI-XVII), Universidad de Extremadura, 1990, pp. 41-43.
} 
que son las dos obras que Teresa de Jesús mejor conocía por su lectura en diversos pliegos sueltos, se suprime la oposición entre poesía culta y popular, asegurando la supervivencia de las canciones por medio de la música. Al componer sus poesías, Teresa fue consciente de esta unidad de lo popular y lo culto, recogida por el Cancionero general, y cuya continuidad fue favorecida por la difusión de los pliegos sueltos. Así pues, la poesía en la cual pudo formarse una joven nacida en los comienzos del siglo XVI, como Teresa de Ávila, fue la poesía del siglo XV, que sigue la tradición del amor cortés, usa un vocabulario bastante limitado y cuyos procedimientos retóricos más destacados, como la antítesis, la paradoja y el oxímoron, expresan la contradicción del amante atormentado. Si además tenemos en cuenta que el siglo XV es una época profundamente vital, llena de tensiones extremas, comprendemos el uso de la imagen como representación de los sentidos. Por eso, a la hora de valorar la poesía de Teresa de Jesús, nos encontramos con la alquimia de una estética, que se construye, a nivel afectivo, sobre la diferencia entre lo visible y lo no visible, lo aparente y lo real, y de la que podríamos destacar los siguientes rasgos:

1) La oración como forma de comunicación con Dios. Para Teresa, la oración, nacida del impulso interior, traduce una dinámica de metamorfosis, un tránsito de las formas, hecho posible a través de la figura de Cristo, el Verbo encarnado. Y si a lo largo de sus escritos en prosa la oración es un medio de "poder tener comunicación no menos que con Dios" (Moradas, 1, 6), utilizará las formas del lenguaje apelativo, la invocación, la exhortación y el diálogo, para expresar su "trato de amistad" con Dios. Expresiones tan reiteradas como "gracia recibida" $\mathrm{y}$ "tener espíritu" nos hablan del poder comunicativo de la palabra, que llega a su máxima expresión en su libro Exclamaciones, cuya escritura en prosa alcanza la tensión propia de lo poético, y en el poema "Ya no durmáis", ("Ya no durmáis, no durmáis, / pues que no hay paz en la tierra"), revela una situación de desvelo ante lo ausente, propia de lo poético. Toda la vida de Teresa de Jesús fue una historia de oración. En su escritura, la oración aparece como nexo entre experiencia y palabra, entre lo efímero y lo eterno, que da unidad a todo el proceso místico ${ }^{7}$.

2) La aventura del cuerpo. La experiencia mística, en cuanto traduce la unidad de cuerpo y espíritu, apunta a una totalidad de lo real, a la que aspira la palabra poética. Teresa de Jesús no ve el cuerpo como tumba del alma, según la consideración de Platón, sino que lo concibe como presencia de lo ausente, ya que no se puede acceder a lo espiritual sin la complicidad de lo corpóreo. En el Libro de la vida $(22,10)$, ella misma

\footnotetext{
${ }^{7}$ Teresa de Jesús concibe la oración como ejercicio para la vida mística. En este sentido, véase el estudio de M.Herraiz García, La oración, historia de amistad, Madrid, Editorial de Espiritualidad, 1982. En cuanto al poder comunicativo del habla teresiana, que está próximo, en muchos casos, a las formas del lenguaje oral, remito al ensayo de José Jesús de Bustos Tovar, "Oralidad y escritura en el siglo XVI: el caso de Santa Teresa", en Santa Teresa o la llama permanente: estudios históricos, artísticos y literarios, (Coords.), E.Borrego y J.Olmedo, Madrid, Centro de Estudios Europa Hispánica, 2017, pp.221-244.
} 
nos dice: "Tornando a el segundo punto, nosotros no somos ángeles, sino tenemos cuerpo; queremos hacer ángeles estando en la tierra -y tan en la tierra como yo estauaes desatino, sino que ha menester tener arrimo el pensamiento para lo ordinario, ya que algunas veces el alma salga de sí, u ande muchas tan llena de Dios que no haya menester cosa criada para recogerla". De ahí el deseo de morir, de abandonar la vida terrena para alcanzar otra más alta ("¿Quién es el que teme / la muerte del cuerpo, / si con ella logra / un placer inmenso?", leemos en el poema "Ayes del destierro"). Si el Evangelio es una noticia carnal, pues "el Verbo se hizo carne", entendemos las afirmaciones de Tertuliano ("La carne es el fundamento de la salvación", De resurrectione, 8, 2), y de fray Luis de León ("Que es decir que somos un cuerpo con Christo, y que nuestra carne es de su carne, y de sus huessos los nuestros, y que no solamente en los espíritus, mas también en los cuerpos, estamos todos ayuntados y unidos", dice el sabio agustino al hablar del "Esposo", en De los nombres de Cristo). Ambas afirmaciones pueden comprenderse desde la asunción de lo corpóreo, presente a lo largo de la tradición cristiana, pues la conciliación cuerpo-espíritu apunta ala indistinción característica de la experiencia mística8 ${ }^{\text {. }}$

3) La plasticidad de las imágenes. Dentro de la tradición religiosa, que muestra un proceso de analogías e intercambios, el escritor místico se vale de las imágenes y los símbolos para expresar la unión del alma con Dios. Y así como san Juan de la Cruz utiliza el símbolo de la "noche oscura" para revelar la unidad de la transformación amorosa ("Oh noche que juntaste / Amado con amada, / amada en el Amado transformada!", Noche oscura, 5), santa Teresa se sirve del carácter representativo de la imagen, de su valor vivo y dinámico, para sugerir el estado de separación o desapego y entrar en el éxtasis de la unión. De las imágenes y símbolos más utilizados, "el agua", "el gorrión”, “el dardo", “la cruz”, “la mariposa”, "el trono” y "el castillo”, tal vez sea "la cruz", como forma de identificación con la figura de Cristo, y "el castillo", como camino hacia el centro, los que aparecen como núcleo de su escritura. Mientras "el castillo" se convierte en la síntesis de la experiencia mística en las Moradas (1577), pues todo el empeño de la santa es "llegar a la morada principal", es decir, a la morada séptima, donde tiene lugar la unión transformante, el de "la cruz" es el que más se reitera en su poesía, consciente de utilizar un símbolo de significación universal, en el que convergen lo vertical y lo horizontal, el cielo y la tierra, según nos dice el estribillo de su poema sobre "La cruz", donde ésta se revela como el camino que une el cielo

\footnotetext{
${ }^{8}$ El cuerpo es la experiencia del alma, la experiencia de tocar indefinidamente lo intocable. De ahí que, a nivel lingüístico, el cuerpo aparezca como límite del discurso, como la exposición de un sentido. Por eso, señala Jean-Luc Nancy: "Todo el asunto está ahí: un cuerpo corresponde a la extensión. Un cuerpo corresponde a la exposición. No sólo que un cuerpo es expuesto, sino que un cuerpo consiste en exponerse. Un cuerpo es ser expuesto", en Corpus, Madrid, Arena Libros, 2003, p. 95. En cuanto a la complicidad de cuerpo y espíritu en la escritura teresiana, véase el ensayo de J.A.Valente, “Teresa de Ávila o la aventura corpórea del espíritu”, en La palabra y el centro, Madrid, Taurus, 1983, pp. 29-36.
} 
y la tierra ("y ella sola es el camino / para el cielo"). Al revestirse la cruz del cuerpo resucitado de Cristo, ilumina nuestro ser ("nos da luz") y nos devuelve a la unidad del paraíso perdido ("árbol de vida"). En la simplicidad de ese símbolo unificador, cuyo eje cósmico contiene el universo, es posible tener una visión sintética de la realidad, de la unidad de cuerpo y espíritu, sustancia de toda mística. La cruz sería el punto donde se funden los contrarios, donde se dice la totalidad?.

Teresa de Ávila escribió sus poesías para las monjas de sus conventos e insertó en ellas las formas cantables más conocidas, coplas, romances y villancicos, que no son un mero añadido, sino que cumplen una función divulgadora. Aunque resulta difícil ordenarlas cronológicamente, todas ellas muestran una variedad estilística, sometida a la dialéctica de la repetición y la invención, lo cual revela una lectura y conocimiento de los motivos y las formas de la lírica cancioneril. Como los poetas cortesanos, Teresa utiliza la glosa del estribillo anónimo, que sirve de base a la canción entera, para insertar un motivo profano en un contexto religioso, acompañándolo con la música para llegar con más facilidad a los oyentes. Por otra parte, el grado de sublimación que se observa en el paso de lo profano a lo religioso, del que es un ejemplo notable la técnica de los contrafacta, terreno a la vez incierto y sugerente, implica la aceptación de los códigos de la poesía cancioneril, donde el amor y la poesía se reducen a puro juego cortesano, que sirve para que el poeta pueda lucir su ingenio y el público participar activamente. Según el complejo y reglamentado arte de la galantería, el hombre "avisado y discreto" será aquel que reúna la doble condición de poeta y enamorado. El amor se identifica con la disposición para la poesía: "Per amor es om cortés", había dicho el trovador provenzal Raimon de Miraval. El éxito alcanzado por las poesías teresianas, más entonces que ahora, se debe a la mezcla del estilo artificioso y el lenguaje coloquial para expresar las contradicciones de un amor imposible, pues el servicio fiel a una dama que no recompensa al amante, propio del amor cortés, le lleva a padecer el sufrimiento para probar su amor y a desear la muerte como medio de liberación ("Vivo sin vivir en mí"). Si a partir del Concilio de Trento la influencia del poder religioso fue cada vez mayor en la vida pública, no resulta extraño que la escritora abulense recurra a los juegos cortesanos de la lírica cancioneril, basados en la retórica del fingimiento, no sólo para burlar la censura, sino también para expresar la angustia de tener que fingir estar viva, estando crucificada entre el cielo y la tierra. Esta mística del sufrimiento, encarnada por el gorrión solitario o la mariposa voladora en su viaje a lo imposible,

\footnotetext{
${ }^{9}$ En cuanto a la relación de la cruz con el Árbol dela vida, que aparece como eje del mundo, véase el estudio de R.Guénon, El simbolismo de la cruz, Barcelona, Obelisco, 1987, pp.82-83. Sobre el carácter representativo de las imágenes teresianas, remito a mi ensayo "Teresa de Jesús (1515-2015). El cuerpo de la escritura", en Cuadernos Hispanoamericanos, 777 (2015), pp.106-118. Respecto a la viveza de las imágenes plásticas frente a los esquemas abstractos y conceptuales de la lírica cancioneril, dicho contraste ya fue destacado por R.Lapesa en su célebre ensayo "Poesía de cancionero y poesía italianizante", recogido en De la Edad Media a nuestros días, Madrid, Gredos, 1967, pp.145-171.
} 
revela un esfuerzo, al modo cortesano, de parecer ser viva, de restituir en la palabra, que se presenta como un disfraz a prueba del Amado, una criatura y un alma libre. Leyendo sus poesías, se tiene la sensación de que escribir es un acto de amar, pues sólo el amor nos puede salvar de la muerte ${ }^{10}$.

En la lengua sagrada, la plegaria, anterior a la palabra, es alabanza a Dios, lo mismo que el sacrificio ("Incienso a tu imagen sea mi plegaria / y mis manos alzadas / un sacrificio vespertino", dice el Salmo 141, 2). Y como para Teresa la vida no tiene sentido si no se reza, la oración le sirvió para establecer un vínculo entre el mundo y la palabra, para volver al origen, objeto de la poesía. Escribió poesía porque tenía un alma musical y sabía dar ritmo a sus poemas. Es una música que surge de la oscuridad y habla de lo profundo, destinada a elevarse desde la fuerza de su dolorosa espera, de ahí que invite a la plegaria con el estremecimiento de ser sustancia viva. Vueltos hacia su propio interior, sus poemas potencian su energía sonora desde la desnudez de su fingida retórica y nos hacen volver el oído hacia Dios, buscando la recuperación del orden perdido. Si la palabra poética es un vacío modelado, próximo a la nada de la germinación, los poemas que Teresa nos ha dejado apuntan a una extraña salvación desde lo profundo de la espera, dejando que lo divino actúe en el alma y la palabra recupere la sustancia sonora y primordial del origen. Por estar cercana a la invocación, su palabra se hace tránsito del alma hacia la unión con Dios, como ocurre en la experiencia mística, despojándose de cualquier estorbo y dejando escuchar lo que viene de lo alto. En un tiempo de simulación, marcado por el juego fingido de aparentes contradicciones, cada poema suyo ofrece una gradual revelación, que lleva la palabra hasta su extrema desnudez y se esfuerza por manifestar el encuentro con lo absoluto. En tanto que su poesía desea penetrar más allá de lo visible, lo que se percibe en cada uno de sus poemas es un esfuerzo por liberarse de los códigos del lenguaje estilizado, convirtiendo su escritura en un acto de afirmación personal frente a las formas del poder establecido.

\section{BIBLIOGRAFÍA}

BARANDA, N., “Tomas de velo: deslindes preliminares”, Bulletin Hispanique, 113 / 1 (2011), pp.269-296.

\footnotetext{
${ }^{10}$ Para los distintos períodos de la tradición cortesana, en la que la elaboración del poema se hace a partir del estribillo tradicional, seguido de las variantes de la glosa culta, véase el estudio de V.Beltrán, La canción de amor en el otoño de la Edad Media, Barcelona, PPU, 1988. Sobre la técnica de los contrafacta, remito al estudio de B.W.Wardropper, Historia de la poesía a lo divino en la cristiandad occidental, Madrid, Revista de Occidente, 1958. En cuanto al lenguaje coloquial como forma de transgredir las convenciones del lenguaje estilizado, tengo en cuenta, entre otros, el ensayo de R.Navarro Durán, “Con toda verdad y llaneza: la eficacia de la escritura sin ornato", en Teresa de Jesús: V Centenario de su nacimiento, historia, literatura y pensamiento, (coord..) J.García Rojo, Diputación de Salamanca, 2015, pp.131-149.
} 
Beltrán, V., La canción de amor en el otoño de la Edad Media, Barcelona, PPU, 1988.

Benito De LucAs, J., La poesía de Santa Teresa (Entre la tradición y lo divino), Madrid, Rialp, 2015.

Bustos Tovar, J. J., “Oralidad y escritura en el siglo XVI: el caso de Santa Teresa”, E. Borrego y J. Olmedo (coords.), Santa Teresa o la llama permanente: estudios históricos, artísticos y literarios, Madrid, Centro Estudios Europa Hispánica, 2017, pp. 221-244.

Casas Rigall, J., Agudez y retórica de la poesía de cancionero, Universidad de Santiago de Compostela, 1995.

Gómez Solís, F., Imágenes eróticas y bélicas de la literatura espiritual española (Siglos XVIXVII), Universidad de Extremadura, Cáceres, 1990.

GuÉnON, R., El simbolismo de la cruz, Barcelona, Obelisco, 1987.

HatzFeld, H., Estudios literarios sobre mística española, Madrid, Gredos, 1955.

Herraiz García, M., La oración, historia de amistad, Madrid, Espiritualidad, 1982.

JANÉs, C., Guardar la casa y cerrar la boca, Madrid, Siruela, 2015.

LAPESA, R., "Poesía de cancionero y poesía italianizante”, De la Edad Media a nuestros días, Madrid, Gredos, 1967, pp.145-171.

López Castro, A., “Teresa de Jesús (1515-2015). El cuerpo de la escritura”, Cuadernos Hispanoamericanos, 777 (2015), pp.106-118.

MARichal, J., “Santa Teresa en el ensayismo hispánico”, La voluntad de estilo, Barcelona, Seix Barral, 1957, pp.71-80.

Nancy, J. L., Corpus, Madrid, Arena Libros, 2003.

Navarro Durán, R., "Con toda verdad y llaneza: la eficacia de la escritura sin ornato", Teresa de Jesús. V Centenario de su nacimiento: historia, literatura y pensamiento, (coord.), J.García Rojo, Diputación de Salamanca, 2015, pp.131-149.

Orozco, E., “De la experiencia mística a la experiencia poética. Oración y poesía”, Expresión, comunicación y estilo en la obra de Santa Teresa, Diputación de Granada, 1987, pp.127-141.

Poitrey, J., Vocabulario de Santa Teresa, Madrid, FUE, 1983.

RiBerA, F. de, La vida de la madre Teresa de Jesús, Barcelona, Gustavo Gili, 1908.

StegGink, O., y De La Madre De Dios, E., (eds.), Santa Teresa de Jesús, Obras completas, Madrid, BAC, 2017, novena edición.

Thiébaux, M., The Stag of Love. The chase in medieval literature, Cornell University Press, 1974.

Underhill, E., La mística, Madrid, Trotta, 2017.

VAlEnTE, J. A., “Teresa de Ávila o la aventura corpórea del espíritu”, La piedra y el centro, Madrid, Taurus, 1983, pp.29-36.

WArdropper, B. W., Historia de la poesía a lo divino en la cristiandad occidental, Madrid, Revista de Occidente, 1958.

Whinnom, K., La poesía amatoria cancioneril en la época de los Reyes Católicos, University of Durham, 1981. 